\title{
Retinoblastoma-Associated Protein Staining Method
}

National Cancer Institute

\section{Source}

National Cancer Institute. Retinoblastoma-Associated Protein Staining Method. NCl

Thesaurus. Code C122867.

An immunohistochemical technique used to detect the presence of retinoblastomaassociated protein in a tissue sample. 